\title{
THE (TRANS)FORMATION OF RELIGIOUS CAPITAL IN INDONESIAN POLITICS DURING NEW ORDER ERA: A Case Study of Nahdlatul Ulama
}

\author{
Muhammad R. Damm \\ Universitas Indraprasta PGRI, Jakarta, Indonesia \\ Email:muhammaddamm@gmail.com
}

\begin{abstract}
Religious capital always has a crucial role in Indonesian politics. This paper aims to analyze the formation of religious capital in the New Order era that has been heavily influenced by the dynamics of the relationship between the state and religious groups, especially Islam, over time. As a case study, this paper will discuss Nahdlatul Ulama (NU). By analyzing the development of NU during the course of the New Order, it shows that the formation of religious capital was affected by the New Order's systematic attempts to contain Islamic forces. Since the late I960s until the midst of I980s, the New Order orchestrated a systematic weakening of Islamic movement through destabilization and demonization of the Muslim community. It also attempted systematically to reduce the political power of Islamic elements by sanctioning several policies and regulations, especially simplification of the political party system in 1973 and the enforcement of Pancasila as the sole principle for socio-political life in 1985 . In I984 NU declared its resolution to return to its original status as religious-based social organization, adopted Pancasila as its principle, and formally retreated from politics. However, in the late I980s and during I990s, although institutionally experienced de-politicization, NU proved to remain significant in the political landscape. From this analysis, it is apparent that NU's religious capital comprised of some ingredients: the centrality of ulama, the importance of securing NU community's interests, and the necessity of resources obtained through a good relationship with the state.
\end{abstract}

Keywords: de-politicization, Nahdlatul Ulama, New Order, politics, religious capital

\begin{abstract}
Abstrak
Modal keagamaan senantiasa memiliki peran krusial di ranah politik Indonesia. Tulisan ini bertujuan untuk menganalisis pembentukan modal keagamaan pada masa Orde Baru yang amat dipengaruhi oleh dinamika dari waktu ke waktu relasi antara negara dengan kelompok-kelompok keagamaan, khususnya Islam. Sebagai studi kasus, tulisan ini akan mendiskusikan Nahdlatul Ulama (NU). Dengan menganalisis perkembangan NU selama masa pemerintahan Orde Baru, tulisan ini menunjukkan bahwa pembentukan modal keagamaan tersebut dipengaruhi oleh upaya-upaya sistematis Orde Baru untuk menundukkan kekuatan Islam. Semenjak akhir I96o-an hingga pertengahan 1980-an, Orde Baru melakukan pelemahan sistematis terhadap gerakan Islam melalui destabilitasi dan demonisasi komunitas Muslim. Ia juga berusaha secara sistematis mereduksi kekuatan politik Islam dengan memberlakukan berbagai kebijakan dan regulasi, khususnya penyederhanaan sistem kepartaian pada 1973 dan pemberlakuan Pancasila sebagai asas tunggal kehidupan sosio-politik pada I985. Pada I984 NU mendeklarasikan
\end{abstract}


resolusinya untuk kembali ke status asalinya sebagai organisasi sosial berbasis agama, mengadopsi Pancasila sebagai asasnya, dan secara formal undur diri dari politik. Namun demikian, pada akhir 1980-an dan selama I990-an, kendati secara institusional telah mengalami depolitisasi, NU tetap membuktikan arti penting keberadaannya di kancah perpolitikan. Dari analisis ini, terlihat bahwa modal keagamaan NU terbentuk dari beberapa bahan baku: sentralitas para ulama, pentingnya mengamankan kepentingan komunitas $N U$, dan perlunya memperoleh sumber daya melalui relasi yang baik dengan negara.

Kata kunci: de-politisasi, Nahdlatul Ulama, Orde Baru, politik, modal keagamaan

\section{INTRODUCTION}

Despite its secular constitution, Indonesian politics always has a room for religion to play a significant role. In fact, capitalization of religion effectively provides political actors with valuable resources for achieving their political interests and aspirations. Therefore, in the context of Indonesian politics, religion does not stop as an identity. It is also a capital. Following Bourdieu, capital here is defined as resources which can be used to improve or to maintain one's position However, religious capital is not a mere capital that emerges from the religious field. It is also the capitalization of religion that can be used in the religious field as well as the others, particularly in politics (Gauntlett, 20II). Thus, this paper scrutinizes the formation of religious capital in Indonesian political context, and also argues that the formation of religious capital has been shaped by the dynamics of the relationship between the state and religious groups over time. This paper takes the development of Nahdlatul Ulama (NU), the biggest Islamic social organization in Indonesia, as the case study to provide an empirical background for discussing the problem. The choice of New Order (Orde Baru) era as the context to the analysis is rather arbitrary and was made primarily as a temporal limitation to this study, but it is adequate to help to deliver the argument of this paper properly.

During the course of the New Order that lasted more than three decades, NU's development has been influenced by the Soeharto administration's approach towards Islamic (social) forces. This approach was nuanced by a dynamic shifting from time to time, oscillating between antagonistic and accommodative stances, but always has a defined purpose of containing Islamic forces in order to preserve the regime. Soeharto's New Order envisioned its own national model based on its interpretation of Pancasila as the state ideology, and since its early years, tended to perceive Islam as a threat to national unity whenever it grew too strong. So, it was necessary for the New Order to contain Islam and keep it controllable through orchestrated policies and actions that systematically prevented the growth of Islamic forces in society.

Because of those New Order's systematic efforts to reduce Islamic forces, $\mathrm{NU}$ as one of the major political forces during the I960s-I970s, had retreated gradually from the political field. The peak was the return to its 1926 original status and the adoption of Pancasila as its principle in the midst of I980s. Since it embraced Pancasila and formally retreated from politics, NU has been focusing its movements in the socio-cultural field. Institutionally, it has undergone 'de-politicization'; but in fact, some of its leaders and figures have been maintaining their political activities. With the absence of NU political wing, they nurtured and then established their political carrier by joining Golkar Party or other socio-political forces. And eventually, the National Awakening Party (Partai Kebangkitan Bangsa/PKB) was founded in 1999 as an effort to resurrect NU's political wing after the fall of the New Order. During this period, roughly began in the midst of I980 until the collapse of the New Order in I998, religious capital was being used in politics "indirectly." Institutionally, NU was not active politically in a struggle for power. However, may of its leaders and figures successfully capitalized their influence, connection, and affiliation with the organization to affect the outcomes of the political process. By elaborating its religious capital, molded through fluctuating relationship between the state and religious elements in the 
political field, NU proved to remain significant in I99os political landscape, even influential in affecting the result of a general election, despite its status as a non-political organization.

In order to discuss the formation of religious capital in the New Order era, focusing on the case of $\mathrm{NU}$, this paper is organized in several sections. The first section provides a definition of religious capital and its conceptualization with regard to NU case. The next two sections discuss how the New Order strived to control Islamic forces and NU's response to such efforts resulting in the formation of its religious capital. The discussion focuses on two main topics: the demonization and destabilization of the Islamic community by the regime and the weakening of Islamic politics through several policies and regulations. The fourth section discusses how NU, now as a non-political organization, elaborates its relationship with the state to keep its significance in the political field. The paper ends with a brief conclusion dedicated to reasserting its thesis.

This paper is written based on a desk study with the sources of materials come from works of literature and documents related to the history of NU, particularly during the course of the New Order. They include many publications (books, scientific articles, news articles, official publications) related to NU and archives owned by NU. In addition, literature and documents recording or discussing the social and political situation in general during the New Order era were also studied.

\section{RELIGIOUS CAPITAL IN THE CASE OF NAHDLATUL ULAMA}

Despite its growing significance in understanding current social life along with the revival of religion and spirituality in many parts of the world, religious capital (or spiritual capital) remains lack of clear definition (lannaccone and Klick, 2003). There are plenty of definitions with each author stressed on a certain aspect of this capital. Some even prefer to utilize 'spiritual capital' instead of 'religious capital' to emphasize the significance of 'spirituality' as something different with 'religiosity' and at the same time prevent its conceptualization being saturated by the association to institutional religion (lannaccone and Klick, 2003). However, the general tendency among authors is to understand it as a subset or subspecies of social capital or cultural capital. Based on their interpretation of Bourdieu's notion on religious capital, Berger and Hefner (2005) concluded that 'spiritual capital might be thought of as a subspecies of social capital, referring to the power, influence, knowledge, and dispositions created by participation in a particular religious tradition.

According to Bourdieu and Wacquant (I992: II9), social capital itself refers to 'the aggregate of the actual or potential resources which are linked to possession of a durable network of more or less institutionalized relationships of mutual acquaintance and recognition-or in other words, to membership in a group.' However, we must note that Bourdieu's account of capital is always connected to a particular field; therefore, religious capital is specific to the religious field. It is at this point that the use of religious capital as a conceptual framework in this paper departed from Bourdieu's conceptualization. As this paper will show it, the resources which are linked to the membership in a religious group can be used in other fields, especially in politics.

On the other hand, Baker and Smith (2010) noted that Bourdieu also saw religious capital 'as functioning in a similar way to cultural capital,' since religious capital is seen as 'the amount of knowledge and practice pertaining to religious culture one can bring to bear, and this knowledge and practice determine ones' hierarchical status in the religious field'. This understanding is closely related to the function of religious capital to make $a$ distinction, i.e., as 'cultural signifier' used by people 'to identify themselves with those "above" them on the social ladder and to demonstrate their difference from those "below"' (Gauntlet, 20II). As a cultural capital, people gain it by obtaining religious knowledge and conducting religious practices that are commonly expressed through some symbols of religious significance so that people of the laity will respect them. 
According to McKinnon et al. (20II), the distinction between those who have access to the religious capital and the laity can be maintained and reinforced 'only if the priestly body disguises their worldly (political) interests, and the lay people misrecognize the objective nature of the priestly monopoly over the goods of salvation.' This notion tends to put those who hold religious capital as duplicitous actors, especially when they enter the political field. This paper is in agreement with the view that religious capital, through the utilization of religious symbols, discourses, and issues, can be used to win, or at least to fight, the struggle in the political field. However, the empirical data that is about to be discussed in this paper shows that in such struggle it is not necessary to be duplicitous, since the meaning of the struggle in the political field is sometimes understood as the struggle for religious ideals, either by 'the elite' or by 'their constituents.'

As Fealy (2009) noted, in the case of Indonesia's NU, a viewpoint similar to abovementioned notions by McKinnon et al. (2OII) can be easily seen in many pieces of literature discussing NU from the I950s until I970s that are dominated by modernist perspective. Writers who adopted this perspective were mostly modernist Muslims and Western scholars. Their accounts about traditionalist NU tended to sound negative by characterizing it as 'opportunist' (Fealy, 2009: 4). They saw NU as a social organization that easily compromises its Islamic ideals in order to gain from current political development. Contrarily, Fealy, and some other scholars such as Nakamura (I98I), tried to understand NU with a more sympathetic view. In accordance with his interpretation, it is more appropriate to understand NU's 'opportunism' as a kind of flexibility in responding to the ever-changing situation of Indonesian sociopolitical life. It was evident that the more flexible NU had more resilience than the more rigid Masjumi so that it succeeded in surviving the harsh politics of the I950s-I96os (Bush, 2009).

In the case of NU, there is a crucial difference between the modernist approach and more sympathetic approach concerning their explanation of the relationship between religion and politics. Modernists view NU as an organization that places political interest as an end, whereas religion both as ideal and as identity is mostly a means to that end. On the contrary, Fealy and other sympathetic scholars understand the matter differently. It is true that $\mathrm{NU}$, during the course of its existence since I926, tends to side with the ruling government and avoid hostile antagonism with them, although occasionally expressing opposition or criticism towards the regime. It was apparent at the time when Soekarno, backed by the military, planned to end the parliamentary system and replaced it with Guided Democracy (Demokrasi Terpimpin). Formerly opposed it and defended the parliamentary system, NU finally took an accommodative turn. Fealy (2009: I89) noted that NU leaders eventually argued that all-out opposition towards Guided Democracy would only result in NU's exclusion from the structures of political power. Some quite similar inclinations were also apparent during the New Order era. Occasionally showing criticism, NU tended to be more accommodative every time Soeharto became more repressive and intolerant with opposition (Bush, 2009) - that is when NU leaders considered it would bring more damages for $\mathrm{NU}$ and its community if they were persistence with their criticism. However, it didn't mean they blatantly used religion in order to achieve access to power. Instead of using religion for political purposes, they simply recognized the importance of political support from the ruling government to maintain their survival. Indeed, the ruling government's support was important, since a lot of NU's traditional boarding schools (pesantren) received substantial funding from government and tens of thousands of $\mathrm{NU}$ people work as civil servants (Bush, 2009: 52). In other words, NU places politics merely as one of many means to serve Muslims' interest.

With this sympathetic view in understanding NU, we can see that the capitalization of religion to develop religious capital is not a sort of 'one-way' mechanism by which one variable (religion) simply serves as a means to another end (political interest). Religion indeed facilitates the development of access to power in politics, especially when identity politics is 
in the play. But, the other way round is also in working; in its turn, the importance of access to power itself is understood as an instrument to achieve a higher purpose that is religious interests. In this context, it is important to understand that as a social organization with vast but loose memberships, NU tends to see the manifestation of Islam's interests in the sustainability of its community rather than in an ideal abstract need to aspire, yet to come. This strong perception of religious interest as embodied in the survival of its religious community contributes to NU's inclinations to be pragmatic-some outside observers may see it as 'opportunistic,' but it is also ignorant to deny that NU behaves in a way it sees fit with its ideals.

In subsequent sections, we will see the formation of NU's religious capital as a byproduct of fluctuating and the elaborative relationship between NU and the state. In understanding this relationship, however, it is requisite to keep in mind that both $\mathrm{NU}$ and the ruling government had their own internal dynamism over the course of the New Order regime. This internal dynamism undoubtedly was affecting and affected by the relationship itself, so that both of the parties were always showing ever-changing moves and attitudes in order to sustain and respond to each other.

\section{DEMONIZATION AND DESTABILIZATION OF MUSLIM COMMUNITY}

The period of the I96os witnessed the decline of Soekarno's reign as the first President of the Republic of Indonesia until he was succeeded by Soeharto who walked his path to power patiently-many scholars characterized it as 'creeping coup' (Crouch, I978; Roosa, 2006: 4; Kusuma, 20I2: 133). The so-called failed coup by Gerakan 30 September (G30S), allegedly orchestrated by PKI, provided General Soeharto (who was the Commander of the Army's Reserved Troops at the time) with an opportunity to destruct $\mathrm{PKI}$, one of the major forces in Indonesian politics in early I96os and also the Army's main enemy; while nurturing his own path to seize power from Soekarno. He started by leading the campaign to destroy PKI in I965-I966; receiving mandate to maintain order from Soekarno through Surat Perintah II Maret (Supersemar) in March I966; becoming the Chairman of Ampera Cabinet Presidium in July 1966; and receiving mandate as in-acting President (Pejabat Presiden) in March I967, until his official presidency that began on 27 March 1968.

As PKI's forces and Soekarno's regime were crumbling, a dramatic change in power structure opened a chance for Islamic forces to rise again in the arena of politics. During the anti-Communist campaign, Islamic forces took a significant role and gave crucial support to the Army. In some regions, groups of santri from $\mathrm{NU}$ and Muhammadiyah actively participated in the campaign (Bertrand, 2004). Confident with their support and contribution in devastating Communist forces, Islamic groups had a big hope to the new regime after the fall of Soekarno (Bertrand, 2004; Kusuma, 2012). During the early years of the New Order, there was a close relationship among sociopolitical forces that previously formed an alliance to hit PKI, especially between NU and the Army (Sitompul, I989: I6I). In the ruling cabinet and parliament, NU gained a strong influence and power. Some of its central figures occupied important positions in state body and government agencies, such as H. M. Subchan Z. E. who assumed Vice Chairman of MPRS, K.H. Achmad Syaichu who assumed the Chairman of DPR-GR, and K.H. Mohammad Dahlan who assumed the Minister of Religion. It was reasonable, then, if Muslim community thought that the new regime would nurture a more positive relationship with Islam so that Islamic forces could regain its power that had been repressed by Soekarno (Sitompul, I989: I62). However, the New Order had its own plan. It showed a tendency to limit Islamic forces since its early days and tried to subordinate them under the state, ruling through manipulation, cooptation, and repression (Bertrand, 2004).

In its early years, the New Order politically exploited some issues to discredit Islamic parties. These issues were rooted in the past, especially in the latest years of Soekarno's presi- 
dency. In the i950s some Muslim figures joined Darul Islam (DI) rebellion in West Java, and in February 1958 some Masjumi politicians joined Revolutionary Government of the Republic of Indonesia (Pemerintahan Revolusioner Republik Indonesia/PRRI) in Sumatra and Sulawesi (Bertrand, 2004: 72). The Indonesian Army was unsuccessful in defeating the 'rebellion' of Darul Islam/Indonesian Islamic Army (Darul Islam/Tentara Islam Indonesia or DI/TII) that was promoting Islamic state of Indonesia, until it captured and executed DI/TII's leader, S. M. Kartosuwiryo, in I962 (van Bruinessen, 2002). All of these issues contributed to the suspicion of the government towards the Muslim community and their sociopolitical activities. Consequently, it limited the movements of Islamic forces and even weakened them. Aware of the situation, in addition to a long dispute with modernist elements in Masjumi, during the I950s until early i96os NU had attempted to brand itself as a face of more tolerant Indonesian Muslims that was different with Masjumi (Bush, 2009).

During the course of its reign, the New Order exploited national unity discourse to justify repression towards an alternative narration of nationalism. After the devastation of PKI and its ideology, the threat to the New Order was frequently depicted as a threat to national unity and Pancasila ideology. In this context, Islamic forces were frequently perceived and positioned as the biggest threat to the New Order's narration of nationalism (Bertrand, 2004: 82). It then made systematic moves by exploiting many incidents that erupted in the I96os until I980s to oppressed Islamic elements. In the late ig6os, there were interreligious conflicts-especially between Muslims and Christians - that erupted violently in some regions (Anam, I996: I35; Bertrand, 2004: 78-79; Kusuma, 2012: 140). It was caused mainly by the activities of Christian missions that became massive after the anti-Communist campaign (Natsir, I969; Bertrand, 2004: 78). As Bertrand (2004) noted, the strong financial support from international organizations enabled Christian missions to infiltrate Muslim enclaves; it was usually conducted through education in Christian schools, dissemination of religious information, and construction of new churches. Muslim community tended to perceive these activities as a threat so that violent conflicts were easily ignited. Among the notable cases were church arsons in Meulaboh, West Aceh, July I967, and in Makassar, October I967 (Bertrand, 2004: 78). An interreligious dialogue (Musyawarah Antar Agama) initiated by the government on $30^{\text {th }}$ November 1967 was unsuccessful in appeasing the interreligious enmity (Anam, I996: 135; Bertrand, 2004: 79). Less than two years after the dialogue, there was another church arson. This time was in Slipi, Jakarta, in April 1969.

In the I970s and early I980s, some incidents regarded as terrorism also took place, usually as arsons and bombings targeting churches, night clubs, or movie theaters. Those incidents allegedly were linked to a radical Islamist, namely Komando Jihad (van Bruinessen, 2002; Solahudin, 20II; Muqoddas, 20II). Some scholars argued that Komando Jihad and issues related to them were the New Order's creation, initiated by Ali Murtopo, to discredit Muslim community, especially Islamic party PPP, in anticipating I977 election (van Bruinessen, 2002; Bertrand, 2004: 82; Hadiz, 20II: 20; Solahudin, 20II; Muqoddas, 20II). The politics of Islamic elements suffered more pressure and damaged reputation by the eruption of a violent clash between the sympathizers of PPP and Golkar just before the 1982 election. This incident was known as the 'Lapangan Banteng Incident' (Pemberton, I986). At $18^{\text {th }}$ March I982, Golkar was scheduled to hold a political campaign in Lapangan Banteng, Jakarta. While the Golkar sympathizers were waiting for Ali Murtopo, a group of PPP attributed crowd passed by. Because of provocation, the two groups collided and initiated riots that spread to other parts of Jakarta.

Those incidents during the ig6os until I980s provided a fertile ground for issues that tended to discredit Islam (Bertrand, 2004). They had damaged Muslim's reputation, destabilized Muslim community, and consequently, hindered Islamic movements. They also provided a pretext for Soeharto's New Order to implement policies and regulations curtailing Islamic forces. 


\section{THE WEAKENING OF MUSLIM POLITICS AND NU'S RETREATMENT}

In the middle of I967, the government decided to suspend the general election that was initially planned to be held in I968 (Anam, I996: I45). NU leaders and figures were divided in responding the decision. As the Chairman of DPR-GR, one of NU prominent figures, H. Achmad Syaichu, explained that the suspension was necessary due to the 'technical reason' as well as 'political, security, and cost considerations' (Sinar Harapan, 4 Agustus I967). Some NU figures expressed their objection, including $\mathrm{H}$. M. Subchan Z. E., who was a Vice-Chairman of MPRS at the time (Sitompul, I989: I60; Anam, I996: I45). As Sitompul (I989: I60) noticed, NU insisted that the election must be held as soon as possible, and this insistence resulted in I97I election, despite government's initial plan to suspend it until 1973.

Despite all political pressure from Soeharto, Partai NU was well performed in the I97I election. It gained the second position with $18.68 \%$ votes and 58 chairs in parliament, following Golkar that gained $62.82 \%$ votes and 236 chairs (KPU, 20I8). This result alarmed the New Order and made it realize that NU still had the potential power to contend with the regime. Therefore, the New Order government slowly and systematically tried to reduce its power, one of which by appointing Prof. Mukti Ali from Golkar as the Minister of Religion in 1972 (Bertrand, 2004: 75-76), even though since I953 that position has always been held by NU figures. In I973 President Soeharto also initiated a policy meant to simplify party system by forcing some fusion to political parties (Sitompul, I989: 139; Bertrand, 2004: 75; Ufen, 2008: I2). This policy was actually anticipated two years earlier when President Soeharto, not long after I97I election in July, was willing to simplify the composition of the parliament by reducing the numbers of fractions, from $\mathrm{I}_{3}$ fractions to just four fractions. He expressed his will to follow it up so that the simplification would take place not only in the parliament but also in the broader political life (Team Dokumentasi Presiden RI, I991: 345).

In January 1973, the government forced nine political parties to fuse into just two political parties. Therefore, in $5^{\text {th }}$ January United Development Party (Partai Persatuan Pembangunan/PPP) was created from the fusion of four Islamic parties, namely Partai NU, Parmusi, PSIl, and Perti; while Indonesian Democratic Party (Partai Demokrasi Indonesia/PDI) was created from the fusion of five remaining parties, namely PNI, Partai Murba, IPKI, Parkindo, and Partai Katolik (Sitompul, I989: 139; Bertrand, 2004: 75). This forced fusion surely weakened political parties who must compete with Golkar, one of the main New Order's political machines. Since their establishment, PPP and PDI had always been suffering from the unresolved internal conflicts among their elements that were originated from various political stances and aspirations. Consequently, PPP and PDI were always too weak to compete with Golkar in every election during the course of the New Order. The damage was also worsened by NU whose political wing was reduced to be a part of PPP.

During I970s PPP had to endure severe friction between its components. A major division occurred along the line of modernist-traditionalist division. Its modernist elements, especially from Indonesian Muslim (Muslimin Indonesia/MI, formerly Parmusi) slowly undermined the role of NU's figures, including charismatic Kiai and ulama, who were considered obsolete and did not fit in managing modern political organization (Bush, 2009). They also reduced the role of party's Advisory Council (Majelis Syuro) that was dominated by NU ulama to merely performing a consultative function and eventually disbanded it completely in I984 (Bush, 2009: 67). This attitude was in sharp contrast with NU's politics and tradition that highly respect ulama.

As a sociopolitical process, the simplification of political party certainly contributed to systematic emasculation of Islamic movement as a part of New Order's project to establish its own version of the national model of Indonesia. This national model has been formulated based on New Order's interpretation of Pancasila as the sole principle for societal life, especially for civil and political organizations in Indonesia (Sitompul, I989; Bertrand, 2004). NU was the 
first civil organization to accept Pancasila as its principle (Bush, 2009: 77; Sitompul, I989: 185). $\mathrm{NU}$ at the time, differed from other Islamic organizations, tended to be accommodative and compromising towards Pancasila (Salim H. S., 2004: 162). However, this acceptance was not an instant decision. NU had to undergo internal disputes in its way to formulate a proper response to the discourse. At last, NU's relatively 'smooth' process of acceptance was facilitated by their own organizational process that was aspiring to come back to Khittah 1926 and at the same time, try to maintain distance from political practices (Sitompul, I989).

The long road for the New Order to sanction Pancasila as the sole principle can be tracked as far as to the General Assembly (Sidang Umum) of the MPR RI on March I978, particularly at its meeting to discuss Broad Guidelines of State Policy (Garis-Garis Besar Haluan Negara/GBHN). At the meeting, there were two subjects that raised objection from some Islamic elements: first, regarding the proposal to state that (traditional) beliefs were equal to acknowledge religions officially, and second, the proposal to indoctrinate Pancasila (as interpreted by the New Order) massively (van Bruinessen, I994: I05-I06) through a course called the Guidance for Appreciation and Implementation of Pancasila (Pedoman Penghayatan dan Pengamalan Pancasila/P4) (Bush, 2009: 66). Some NU figures who were sat as parts of PPP's fraction (Fraksi Persatuan Pembangunan), led by K.H. Bisri Syansuri, protested the subjects by conducting 'walkout' (Barton, 2002: II4; Bush, 2009: 66; Sitompul, I989: I68). Even though the Tap MPR No. IV/MPR/I978 regarding GBHN that was resulted from the meeting stated at last that the belief towards God is not considered as a religion, K.H. Bisri Syansuri argued the inclusion of the subjects itself in the discussion concerning GBHN was already a threat to the status of Islam as religion (van Bruinessen, I994: I06). It was after this act of walkout that government's intervention towards PPP strengthened. Without any dialogue with the leadership of PPP, the government dismissed the Chairman of PPP, H. M. S. Mintaredja, and substituted him with Djaelani Naro, a crony of
Ali Murtopo (van Bruinessen, I994: IIo; Barton, 2002: II5).

After a streak of political disappointments, in the $26^{\text {th }}$ Muktamar in Semarang, 1979, the leaderships of NU finally decided to initiate a process to turn NU back to Khittah 1926-it meant that NU would restore itself to its root as a religious organization (Sitompul, I989: I76-I77). However, this decision was successful only conceptually, but unsuccessful operationally due to its ever-strong political spirit and overlapping rolesof some leaders that remained active simultaneously in NU and PPP (Sitompul, I989: I76-I77). The tendency to keep addressing political problems was apparent in Musyawarah Nasional (Munas) Alim Ulama NU in Kaliurang, Yogyakarta, 30 ${ }^{\text {th }}$ August $-2^{\text {nd }}$ September I98I (Sitompul, I989). Among the main results of the meeting was the statement that it was not necessary to give another designation to the head of state which according to UUD I945 was President and Highest Commander of the Armed Force (Panglima Tertinggi Angkatan Bersenjata) and according to Tap MPR was Mandataries. In addition, the meeting also recommended that the nomination of Soeharto as President should be delivered constitutionally to MPR at the right time that is after the 1982 election (Sitompul, I989; Kusuma, 20I2: I50-I5I). In other words, it means that I98I Munas did not issue an endorsement for Soeharto to serve another period of the presidency as expected from social and political organizations prior to the general election (Bush, 2009: 68). It surely displeased Soeharto and pushed him to discipline NU by retracting government funding for pesantren and social program for many NU members (Bush, 2009: 68; van Bruinessen, I994).

Because of the failure to return to Khittah 1926 in its organizational practices, NU ulama realized that they needed to reaffirm the restoration of Khittah 1926 in Munas Alim Ulama NU in Situbondo, December I983 (Sitompul, I989: I82; Kusuma, 20I2: I64). It was in this meeting that the forum of ulama was also discussing the acceptance of Pancasila as the sole principle for $\mathrm{NU}$ as a civil organization. Before the meeting, K.H. As'ad Syamsul Arifin met with President Soeharto to convey NU's acceptance of Pancasila 
(Bush, 2009; Kusuma, 2012: 153; Sitompul, 1989: I80). Therefore, by I984 when NU held its $27^{\text {th }}$ Muktamar, it has already accepted Pancasila as its organizational principle despite the ruling about the subject itself was not in effect until I985 when the government officially issued Law $8 / 1985$ about Civil Organization in $\mathrm{I}^{\text {th }}$ June.

Abovementioned dynamic development of NU's stance towards the implementation of Pancasila as the sole principle was highly influenced by the internal situation within NU itself in which a movement to return to Khittah 1926 was growing. As Bush (2009) noted, NU's activities in politics, formerly by Partai NU and then by PPP, gave way to the rise of NU politicians who were based in Jakarta, as contrasted to East Java-based traditional ulama. Slowly, these politicians were taking bigger roles in directing NU's development, while reducing their consultancy with ulama in matters regarding politics and broader organizational interests. Consequently, within NU, ulama's roles were reduced, and their position weakened. In the early I980s, the relationship between Jakarta-based politicians (often dubbed as Cipete group) led by the chair of NU, Idham Chalid, and East Java-based ulama (often dubbed as Situbondo group) led by K.H. As'ad Syamsul Arifin was getting worse. Since the late I970s, Chalid frequently faced criticism for his lack of advocacy within PPP on behalf of NU's interests (Bush, 2009: 68). It peaked in 1982 when Djaelani Naro as the chairman of PPP issued a list of legislature candidates called 'Naro list.' In the list, NU figures such as Rachmat Muljomiseno, Saifuddin Zuhri, and K.H. Masjkur were placed in the bottom so that their chance to be elected was thin (Sitompul, I989: I7I). As the chair of NU, Chalid did not deliver expected response, like protest, to the list. This led to the split between Cipete group and Situbondo group. In May I982 three senior kiais (K.H. As'ad Syamsul Arifin, K.H. Ali Ma'shum, and K.H. Machrus Ali) persuaded Idham Chalid to resign, but he resisted. In January I983, Chalid issued a statement declaring the election of K.H. Ali Ma'shum as rais am to be void (Bush, 2009: 68-69).

The severe conflict between the politicians and the ulama in the r98os was worrisome it pushed the new generation of NU leaders and figures, often dubbed as the third generation, to search for a middle ground to bridge the two groups. Since the I970s this third-generationamong its most prominent members were Abdurrahman Wahid, Masdar Mas'udi, Mahbub Djunaidi, Fahmi Saifuddin, Slamet Effendy Yusuf, Ghaffar Rahman, and Rozy Munir-had been focusing their attention in social activities to improve the religious and economic wellbeing of NU community (Bush, 2009: 70). By I974, they promoted a movement to return to Khittah 1926 and called for NU to withdraw from formal politics that they perceived as resulting in organizational deterioration of NU. With this track record, it was unsurprising when they found a momentum to amplify their aspiration in I980s NU's internal conflict.

With the support from the third generation's movement to return to Khittah I926, ulama group was elaborately promoting this movement to distance NU from politics and return it to its original status as a religious-based social organization. By implementing this move, the politicians' position within NU was weakened, while at the same time ulama's supremacy was successfully reinstated. The retreat from politics and return to Khittah 1926, in this context, then, was a decision necessarily made to restore NU as an organization driven by the supremacy of ulama (Bush, 2009). Furthermore, this retreatment from politics was accompanied by the need to fix NU's relation with the regime. The acceptance of Pancasila as NU's basis principle secured this necessity.

From the discussion in this section, we have seen how NU's acceptance of Pancasila has been developed hand in hand with the shifting of NU's attitude toward the issue that slowly moved to accommodation. Since I978, some NU figures have expressed their refutation to government's will to ruling Pancasila as the sole principle. But in I983, Munas Alim Ulama NU decided to accept Pancasila. This acceptance became official in $27^{\text {th }}$ Muktamar in I984, simultaneous with NU's reaffirmation of its decision to return to its root as a religious organization as stated in Khittah I926. This return to Khittah 1926-which has been initiated for five years 
beforehand as a determination to retreat from political practices-has facilitated NU's acceptance of Pancasila. It was a pragmatic and necessary decision to meet at least two purposes simultaneously: restoring NU's tradition as an Islamic-based social organization driven by traditional ulama and securing NU's relation with the ruling government (Bush, 2009; Ismail, I995; Sitompul, I989).

\section{IN BETWEEN DE-POLITICIZATION AND POLITICAL PRACTICES}

We can say that during I980s NU had been undergoing the final chapter of its 'de-politicization' that started in the early I970s. By means of the fusion among fractions in MPR shortly after 197I election, the fusion of political parties in I973, and government's intervention to PPP's leadership shortly after the General Assembly of MPR in I978, NU's politics was systematically being repressed, reduced, even stripped away. It peaked in 1982 towards the general election, when the internal conflict between NU and MI elements plagued PPP. After the death of K.H. Bisri Syansuri in I980, NU figures had been marginalized in deciding PPP's direction. It was apparent when controversy emerged regarding the list of PPP's legislator candidates that is known as 'Naro list' (Sitompul, I989: I7I). Finally, in I984 NU determined to return its origin as religious-based social organization and embracing Pancasila as its basis. Even though institutionally NU has undergone depoliticization that was completed by its return to Khittah 1926, some of its figures would keep active in political practices. Interestingly, in the late I980s and during I990s, Golkar turned to become the primary canal for those figures to participate in the game. NU's young cadres, particularly who were in Ansor leadership, were among those who enthusiastically participated in politics. They did not represent their organization, but it was obvious that they took advantage of their position in NU to establish their capitals necessary to win the fight in the political field.

There were some reasons that influenced NU figures' preference towards Golkar over PPP as a mean to channeling their political inclinations. The decision to return to Khittah 1926 meant that NU would focus on its original field as an Islamic social organization. After 1984 Muktamar in Situbondo, this decision was stipulated in one of the resulted resolutions, said that as a social organization, NU is not tied to any political or social organization. Bush (2009: 78) observed that this stipulation was not as strong as ulama's resolution to return to Khittah 1926 at I983 Munas Alim Ulama in Situbondo, partly due to influences of $\mathrm{NU}$ politicians that have bigger chance to promote their aspirations in Muktamar rather than in Munas. Consequently, it was opened to different interpretations among NU's members on understanding the exact meaning of the resolution. One of the popular interpretations is that by returning to Khittah 1926, NU has formally resigned from PPP and from national politics in general, but simultaneously it also gives freedom to its members to support or affiliate to any political organizations other than PPP (Kusuma, 2012: I57). During the I987 election, some NU ulama even openly gave their support to Golkar (van Bruinessen, I994: I4I-I49). Accordingly, since the I980s it was not uncommon for NU young figures and Ansor leaders, such as Slamet Effendy Yusuf and Mohammad Iqbal Assegaf, to be active in Golkar. This preference to Golkar, other than pragmatic reason due to its significance as New Order's political vehicle, was also rooted in NU's disappointment towards PPP that got rid of NU elements in the early I980s (van Bruinessen, I994). Although formally NU declared that it took political neutrality at the time, it apparently used this 'neutrality' to weakening PPP and at the same time nurturing a closer relationship with Golkar by moving a substantial portion of voting share from its grassroots from PPP to Golkar. The result of this move was observed on the 1987 election when PPP lost a [significant number of the vote and suffered deflation from $27.8 \%$ vote in the 1982 election to $16.0 \%$ vote in 1987 , while Golkar's vote rose from $64.3 \%$ to $73.0 \%$ at the same period (Bush, 2009: 8I).

This tendency to become de-politicized institutionally, and at the same time freeing its cadres to actively participate in political 
practices has been characterizing NU since the I980s until the late i990s. One of the main actors that navigated NU in sociopolitical climate during this period was Abdurrahman Wahid (Gus Dur), a grandson of NU's founder K.H. Hasyim Asy'ari and a prominent figure of the third generation NU's leaders (Barton, 2002; Bush, 2009; Kusuma, 2012). During the I970s-I980s Gus Dur was among NU's young intellectuals who supported a movement to return to Khittah 1926. He gained significant position when appointed as the director of the Tanfidziyah (the executive branch in NU's organizational structure) in 1984 and became one of NU's most influential figures during I990s period, especially after he assumed NU's chair position (Ketua umum) in I989. According to Kusuma (20I2), after the death of rais is NU K.H. Achmad Siddiq in I99I, Gus Dur became the one who navigated NU in Indonesian politics.

Although Gus Dur was basically an intellectual rather than a politician (Bush, 2009: 69), he proved to be proficient in playing his role as the chair of NU so that NU remained a crucial factor that cannot be ignored in the political landscape. Fully aware of NU's significance, Gus Dur did not let it entirely cut from politics. As a mass organization, NU enjoyed supports from vast grassroots mainly based in Javanese villages. The success of 'deflating' PPP in the I987 election proved how influential NU in national politics, despite its position as a nonpolitical organization. It also made NU thought that Golkar (hence, also the government) owed $\mathrm{NU}$ for their significant increase of vote in the election. In fact, after the 1987 election, NU's relationship with the government got better (Bush, 2009: 8I). After a drastic downturn during the I970s, NU pesantren enjoyed improving government funding (Feillard, I999); Slamet Effendy Yusuf, then the head of Ansor, was appointed to lead the youth division of Golkar's Jakarta branch (Bush, 2009: 8I; Kusuma, 2012), while Gus Dur was appointed as a member of Golkar's fraction in parliament (Bush, 2009: 8I). Although resolution to return to Khittah 1926 forbade NU leaders to occupy political party positions, neither PBNU nor NU figures participated in I989 Muktamar expressed criticism to this development (Bush, 2009: 8I).

However, like in the early I960s, this 'honeymoon' with the New Order did not last. In early I990s NU's relationship with Golkar deteriorated. Bertrand (2004) observed that the period witnessed a significant shift in Soeharto's attitude towards the Muslim community. Since the late I980s until early I990s he apparently distanced himself from Christian and nominal Muslim (abangan) elements that previously comprised his circle of power, including those who took high ranking positions in the armed force and became more accommodative towards Islamic elements. The government allowed Muslim students to wear scarf (jilbab) in public school and assisted the founding of an Islamic bank, as well as sponsored the founding of the Association of Indonesian Muslim Intellectuals (Ikatan Cendekiawan Muslim Indonesia/lCMI) in I990; furthermore, in 1993 Soeharto with his family and associates performed holy pilgrimage to Mecca (haji) (Bertrand, 2004: 83). However, this development was not entirely welcomed by NU. As an organization that was representing modernist Muslim interest, ICMI was perceived as a rival by NU. In addition to this disappointment, NU regarded the government's returns for their contribution to boosting Golkar's vote in I987 as insufficient (Bush, 2009: 82-83). This development contributed to Gus Dur's growing opposition towards the New Order to a point where he became one of the harshest critics to the regime. When Mohammad Iqbal Assegaf, the head of Ansor, publicly expressed his support to Golkar after a meeting with Siti Hardiyanti Rukmana, Soeharto's daughter, on $22^{\text {nd }}$ May 1996, Gus Dur unpleasantly responded by emphasizing NU's neutrality based on Khittah 1926 (Kusuma, 2012: 172). Unlike Slamet Effendy Yusuf who preceded him as the head of Ansor, lqbal Assegaf reaped a bad relationship with Gus Dur for his active involvement with Golkar.

Gus Dur's harsh criticism towards Soeharto and his regime unsurprisingly worried NU leaders and figures who eventually tried to persuade Gus Dur to soften his stance. Moreover, the July 1996 incident of attacking 
of PDI's Jakarta headquarters by governmentbacked mass signaled NU not to openly opposed Soeharto. Some East Java ulama and Jakarta politicians then attempted to reconcile Gus Dur with Soeharto. As the I997 election approached, some developments showed the results of this attempt. In November 1996, Soeharto met with Gus Dur in a NU event, and on the previous day, Gus Dur announced that NU would support Soeharto for another term of the presidency (Bush, 2009: 86). During campaign period of the 1997 election, Gus Dur also escorted Siti Hardiyanti Rukmana on a safari tour to East Java pesantren to introduce her to NU community (Bush, 2009: 86-87; Barton, 2002: 223).

The discussion of this section has shown the dynamic relationship between NU and the state in the last decade of the New Order. Formal retreatment from political practices and institutional de-politicization it underwent in the late I980s did not nullify NU's significance in the political field. During this period, NU's attitudes towards the regime were changing from time to time; it sometimes showed accommodation and sometimes criticism. However, this movement proved to be fruitful in maintaining NU's relevance in the game of power. When the New Order collapsed in I998, NU remained intact and then emerged once again as one of the main political forces in Indonesia.

\section{CONCLUSION}

During the course of the New Order that lasted for more than three decades, the formation of religious capital was determined by the relation between the state and religious community. In this relation, shown by the case of NU, the crucial factors include ulama's supremacy (cultural capital) supported by the massive base at the grassroots level (social capital) and resources provided by the state (mostly economic capital) demanding cooperation (sometimes even submissive obedience) from the religious community. NU proved to survive by elaborating these factors. Ulama's position must face challenges several times-some of those occurred in the I960s-I980s when Muslim community underwent demonization and destabilization, or in the I970s-I980s when NU younger politicians reduced ulama's roles in decision making-but eventually capable of restoring its status quo. In many times NU also took a move pragmatically on behalf of its community by securing government resources allocation through the cooperative relationship with the regime, or simply by showing accommodative attitudes towards the regime in order to prevent damaging effects of regime's oppression. All of those moves evidently contributed not only to NU's survival, but also its significance as sociopolitical forces, either when it actively involved in the political game in the I960s-early I980s or when it retreated from politics but remained influential in late I980s-I990s.

\section{REFERENCES}

Anam, Choirul. (I996). Gerak Langkah Pemuda Ansor: Sebuah Percikan Sejarah Kelahiran. Jakarta: Duta Aksara Mulia.

Barton, Greg. (2002). Gus Dur: The Authorized Biography of Abdurrahman Wahid. Jakarta \& Singapore: Equinox Publishing.

Berger, Peter L., and Robert W. Hefner. (2003). Spiritual capital in comparative perspective. Paper prepared for the Spiritual Capital Planning Meeting 2003.

Bertrand, Jacques. (2004). Nationalism and Ethnic Conflict in Indonesia. Cambridge: Cambridge University Press.

Bush, Robin. (2009). Nahdlatul Ulama and the Struggle for Power within Islam and Politics in Indonesia. Singapore: ISEAS.

Crouch, Harold. (1978). The Army and Politics in Indonesia. Ithaca: Cornell University Press.

Fealy, Greg. (2009). Ijtihad Politik Ulama: Sejarah NU 1952-1967. Yogyakarta: LKiS.

Feillard, Andrée. (I995). NU vis-à-vis Negara: Pencarian Isi, Bentuk dan Makna. Yogyakarta: LKiS.

Gauntlett, D. (2018). Making is Connecting: The Social Meaning of Creativity, from DIY and Knitting to YouTube and Web 2.o. Malden: Polity Press.

Hadiz, Vedi R. (20II). Indonesian Political Islam: Capitalist Development and the Legacies of the Cold War. Journal of Current Southeast Asian Affairs 30(I), 3-38.

lannaccone, Laurence R., and Klick, Jonathan. (2003). Spiritual capital: an introduction 
and literature review. Paper prepared for the Spiritual Capital Planning Meeting 2003.

Ismail, Faisal. (I995). Islam, Politics, and Ideology in Indonesia: A Study of the Process of Muslim Acceptance of the Pancasila. Dissertation, submitted to Institute of Islamic Studies, McGill University, Montreal.

Ketetapan MPR RI Nomor: IV/MPR/I978 tentang Garis-Garis Besar Haluan Negara.

Komisi Pemilihan Umum (KPU). (2 I Februari 2008). Pemilu I97I. Retrieved from www. kpu.go.id/index.php/pages/detail/2018/9/ PEMILU-I97I/MzQz. Accessed at 5 April 2018.

Komisi Pemilihan Umum (KPU). (2I Februari 2008). Pemilu I977-I997. Retrieved from www. kpu.go.id/index.php/pages/detail/20I7/ıo/ PEMILU-I97I-I997/MzQz. Accessed at 5 April 2018.

Kusuma, Erwien. (2012). Yang Muda yang Berkiprah: Gerakan Pemuda Ansor dan Politik Indonesia Masa Demokrasi Liberal hingga Masa Reformasi (I950-2010). Bogor: Kekal Press.

McKinnon, A. M., Trzebiatowska, M., \& Brittain, C. C. (20II). Bourdieu, capital, and conflict in a religious field: the case of the Anglican Communion. The Journal of Contemporary Religion 26(3), 355-370.

Mimbar Demokrasi. (1969). Mohammad Natsir Mengadjukan Tiga Saran untuk Tiga Pihak. Mimbar Demokrasi. No. 85, Tahun III, Minggu III, Mei.

Muqoddas, Busyro. (20II). Hegemoni Rejim Intelijen. Sisi Gelap Peradilan Kasus Komando Jihad. Yogyakarta: PUSHAM UII.
Natsir, Mohamad. (1969). Islam dan Kristen di Indonesia. Bandung: CV Bulan Sabit \& CV Peladjar.

Pemberton, John. (I986). Notes on the I982 General Election in Solo. Indonesia 4I, I-22.

Roosa, John. (2006). Pretext for Mass Murder: the September $30^{\text {th }}$ Movement \& Soeharto's Coup d'Etat in Indonesia. Wisconsin: the University of Wisconsin Press.

Salim H. S., Hairus. (2004). Kelompok Paramiliter NU. Bantul: LKiS.

Sinar Harapan. (1967). Tidak Mungkin Pemilu Tahun I968. Sinar Harapan. August 4.

Sitompul, E. M. (I989). NU dan Pancasila: Sejarah dan Peranan NU dalam Perjuangan Umat Islam di Indonesia dalam rangka Penerimaan Pancasila sebagai Satu-Satunya Asas. Jakarta: Pustaka Sinar Harapan.

Solahudin. (20II). NII sampai JI, Salafy Jihadisme di Indonesia. Depok: Komunitas Bambu.

Team Dokumentasi Presiden RI. (I99I). Jejak Langkah Pak Harto: 28 Maret 1968-23 Maret I973. Jakarta: PT Citra Lamtoro Gung Persada.

Ufen, Andreas. (2008). From Aliran to Dealignment: Political Parties in Post-Soeharto Indonesia. South East Asia Research I6(I), 5-4I.

Van Bruinessen, Martin. (I994). NU: Tradisi, Relasi-Relasi Kuasa, Pencarian Wacana Baru. Yogyakarta: LKiS.

Van Bruinessen, Martin. (2002). Genealogies of Islamic Radicalism in Post-Soeharto Indonesia. South East Asia Research Io(2), II7-I54. 
